\title{
1Enzymatic pretreatment of microalgae using fungal broth from Trametes versicolor 2and commercial laccase for improved biogas production
}

3

4Andrea Hom-Diaz a,\#, Fabiana Passos ${ }^{\text {b,c,\# }}$, Ivet Ferrer ${ }^{\text {b }}$, Teresa Vicent a , Paqui Blánquez $5^{\mathrm{a}, *}$

6

$7^{\mathrm{a}}$ Chemical, Biological and Environmental Engineering Department, Escola 8d’Enginyeria, Universitat Autònoma de Barcelona, E-08193 Bellaterra, Barcelona, 9Spain

10

11 $1^{\mathrm{b}}$ GEMMA - Environmental Engineering and Microbiology Research Group, 12Department of Civil and Environmental Engineering, Universitat Politècnica de 13Catalunya·BarcelonaTech, c/Jordi Girona 1-3, Building D1, E-08034 Barcelona, Spain 14

$15^{\mathrm{c}}$ Environmental and Chemical Technology Group, Department of Chemistry, 16Universidade Federal de Ouro Preto, 35400-000 Ouro Preto, Minas Gerais, Brazil. 17

$18^{\#}$ Andrea Hom-Diaz and Fabiana Passos contributed equally to this work

19

20*Corresponding author: Paqui Blánquez

21Chemical, Biological and Environmental Engineering Department

22Escola d'Enginyeria

23Universitat Autònoma de Barcelona

2408193 Cerdanyola del Vallès. Spain

25E-mail address: paqui.blanquez@uab.cat

26Tel: +34 9358119 79; Fax: +34 935812013

27

This is the author's version of a work that was accepted for publication in Algal research (Elsevier). Changes resulting from the publishing process, such as peer review, editing, corrections, structural formatting, and other quality control mechanisms may not be reflected in this document. Changes may have been made to this work since it was submitted for publication. A definitive version was subsequently published in Hom-Díaz, A. et al. "Enzymatic pretreatment of microalgae using fungal broth from Trametes versicolor and commercial laccase for improved biogas production" in Algal research, vol. 19 (Nov. 2016), p. 184188. DOI 10.1016/j.algal.2016.08.006 


\section{Abstract}

29Coupling microalgae production to wastewater treatment can reduce the costs of 30microalgae production for non-food bioproducts and energy consumption for 31wastewater treatment. Furthermore, microalgae anaerobic digestion can be enhanced by 32applying pretreatment techniques.. The aim of this study is to improve the biogas 33production from microalgal biomass grown in urban wastewater treatment systems by 34applying an enzymatic pretreatment with crude fungal broth and commercial laccase. To 35this end, the fungus Trametes versicolor was cultured, and the enzymatic activity of the 36culture broth analysed by measuring laccase concentration. The results showed that both 37the fungal broth and commercial laccase pretreatment (100 U/L) over an exposure time 38 of 20 min increased the methane yield in batch tests. Indeed, the fungal broth 39pretreatment increased the methane yield by $74 \%$, while commercial laccase increased 40the methane yield by $20 \%$ as compared to non-pretreated microalgal biomass. In this 41manner, laccase addition enhanced microalgal biomass anaerobic biodegradability, and 42addition of $T$. versicolor broth further improved the results. This fact may be attributed 43to the presence of other molecules excreted by the fungus.

44

\section{Keywords}

46Biological pretreatment; Enzyme; Fungi; Laccase; Microalgae; Methane 47 


\section{Introduction}

49Microalgae have long been studied for wastewater treatment because of their high 50capacity for nutrient and organic matter removal in symbiosis with heterotrophic 51bacteria, resulting in a much lower energy requirement compared to conventional 52activated sludge systems which demand mechanical aeration [1]. Furthermore, the 53produced microalgal biomass may be converted into biofuels, including biodiesel, 54biohydrogen, bioethanol, biomethane, or non-food bioproducts, such as biofertilizers 55and biomaterials.

56Biogas production from microalgal biomass through anaerobic digestion has raised 57interest due to the low complexity, minimal processing requirements and availability of 58a technology that has long been used for sludge treatment in wastewater treatment 59plants (WWTP) [2]. Despite the potential of anaerobic digestion, most microalgae 60species growing in WWTP have a complex cell wall composed of resistant structural 61carbohydrates, limiting the hydrolysis step [3]. Thus, pretreatment techniques have 62been studied to increase microalgae solubilisation and methane yield [4], Thermal 63processes at low and high temperatures and mechanical methods like ultrasound and 64microwave enhance microalgae biodegradation and biogas production [5], although the 65energy consumed during the pretreatments may be too high for full scale application, 66especially in the case of mechanical techniques.

67Recently, biological methods like the use of enzymes have been tested. They are 68regarded as a low-cost, eco-friendly pretreatments for enhancing microalgal biomass 69anaerobic biodegradability [6,7]. Enzymes are selected according to the main microalgal 70cell wall compounds namely cellulose, hemicelluloses, pectin, glycoproteins, and even 71lignin $[8,9]$. Indeed, the specific composition depends on the strain, age of the culture, 72nutrient concentration and ambient conditions, among others [6]. The most commonly 
73used enzymes for microalgae pretreatment are commercial $\alpha$-amylases, 74amyglucosidases, cellulases, xylanases, lipases or proteases [10,11]. Furthermore, it has 75been shown that using a mixture of commercial enzymes, the methane yield was higher 76than using a single enzyme specific for one substrate [10,12]. Regarding the use of 77crude fungal enzymes, those from Aspergillus lentullus were particularly effective at 78improving microalgae anaerobic biodegradability [13]. Ligninolytic fungi produce non79specific intracellular and extracellular enzymes, depending on the culture conditions 80[14]. One of the most well-known fungus that produces laccase is the white-rot fungus 81Trametes versicolor. Laccases (EC 1.10.3.2, p-diphenol:dioxygen oxidoreductase) are a 82family of glycoproteins, classified as oxidoreductases that catalyse the monoelectronic 83oxidation of substrates at the expense of molecular oxygen. They are used for cross84linking of monomers, degradation of polymers and ring cleavage of aromatic 85compounds in various environmental applications (e.g. bioremediation of soils and 86wastewater, decolourization of recalcitrant dyes, kraft pulp biobleaching, biorefinery 87processes and degradation of contaminants) [15-19]. In addition, laccase can be used as 88a pretreatment step for cellulose hydrolysis [20].

89The aim of the present study is to evaluate the biogas production increase obtained by 90applying an enzymatic pretreatment to microalgal biomass in biochemical methane 91potential (BMP) tests. Two pretreatment approaches were considered, the first one using 92the commercial laccase enzyme and the second one using crude fungal enzyme from 93Trametes versicolor. This is the first time that the fungal broth from $T$. versicolor culture 94has been used as a microalgal biomass pretreatment for biomethanization. 


\section{$97 \quad 2.1 \quad$ Microalgal biomass}

98In this article, the term microalgal biomass refers to the mixed culture of green 99microalgae, mainly Oocystis sp., diatoms, bacteria and other microorganisms such as 100protozoa, grown spontaneously in experimental raceway ponds treating urban 101wastewater [21]. This microalgal biomass was harvested from pilot raceway ponds used 102for secondary treatment of real urban wastewater, located outdoors at the Department of 103Civil and Environmental Engineering of the Universitat Politècnica de 104Catalunya·BarcelonaTech (Barcelona, Spain). A full description of the system operation 105may be found elsewhere [22]. Average characteristics of harvested biomass are 106summarised in Table 1.

107Table 1 Main characteristics of microalgal biomass (substrate) and digested sludge 108(inoculum) used for BMP tests.

\begin{tabular}{lcc}
\hline Parameter & $\begin{array}{c}\text { Microalgal } \\
\text { biomass }\end{array}$ & Inoculum \\
\hline pH & 7.8 & 7.4 \\
TS [\%(w/w)] & 3.28 & 3.63 \\
VS [\%(w/w)] & 2.07 & 2.57 \\
VS/TS (\%) & $63 \%$ & $71 \%$ \\
COD (g/L) & 31.3 & 31.2 \\
Proteins (\% VS) & 58 & - \\
Carbohydrates (\% VS) & 22 & - \\
Lipids (\% VS) & 20 & - \\
\hline
\end{tabular}

1092.2 Fungus and chemicals

110Trametes versicolor was obtained from the American Type Culture Collection (ATCC

111\#42530). The fungus was serially subcultured on $2 \%$ malt agar slants at $25{ }^{\circ} \mathrm{C}$ until use. 112Glucose, ammonium tartrate dibasic, malt extract and other chemicals were purchased 
113from Sigma-Aldrich (Barcelona, Spain).

\subsection{Trametes versicolor culture}

115A mycelia suspension of $T$. versicolor was obtained by inoculating four $1 \mathrm{~cm}$ diameter 116plugs from the growing zone of fungi on malt agar, in $250 \mathrm{~mL}$ malt extract medium $117(2 \%)$ in a $1 \mathrm{~L}$ Erlenmeyer flask. Flasks were placed on an orbital shaker $(130 \mathrm{rpm}, \mathrm{r}=$ $11825 \mathrm{~mm}$ ) at $25^{\circ} \mathrm{C}$. After 6 days, a thick mycelial mass was formed, which was ground 119with an X10/20 (Ystral GmbH) homogenizer. This suspension was used to produce 120pellets by inoculating $1 \mathrm{~mL}$ of the suspension in $250 \mathrm{~mL}$ malt extract medium $2 \%$ in a 1 121L Erlenmeyer flask. The flasks were incubated on an orbital shaker (130 rpm, $r=25$ $122 \mathrm{~mm}$ ) at $25{ }^{\circ} \mathrm{C}$ for 6 days. The pellets thus obtained were then used for fungal broth 123production.

\subsection{Fungal broth production}

125T. versicolor broth was produced in $250 \mathrm{~mL}$ Erlenmeyer flasks containing $0.9 \mathrm{~g}$ cell dry 126weight of T. versicolor pellets in $100 \mathrm{~mL}$ of medium containing: $8 \mathrm{~g} \mathrm{~L}^{-1}$ of glucose, 3.3 $127 \mathrm{~g} \mathrm{~L}^{-1}$ of ammonium tartrate, $1.168 \mathrm{~g} \mathrm{~L}^{-1}$ of 2,2-dimethylsuccinate buffer, 10 and $100 \mathrm{~mL}$ $128 \mathrm{~L}^{-1}$ of a micro and macronutrient solution, respectively [23]; adjusted to $\mathrm{pH} 4.5$ with 129HCl. Pellets were cultured in six Erlenmeyer flasks, 3 of them were cultured until 130laccase production was $100 \mathrm{U} / \mathrm{L}$ (3.5 days) and the other 3 until glucose was totally 131consumed. Both parameters, laccase production and glucose consumption were daily 132monitored.

\section{$2.5 \quad$ Enzymatic pretreatment}

134Two enzymatic pretreatments were carried out using either the commercial enzyme 135laccase (purchased from Merck (Madrid, Spain)) enzyme or T. versicolor broth. In the 136first case, a stock solution of commercial laccase was prepared and added to microalgal 
137biomass (31 $\mathrm{g}_{\text {wet }}$ ) before BMP tests. The laccase concentration in BMP bottles was 100 $138 \mathrm{U} \mathrm{L}^{-1}$ and the contact time prior to BMP tests was 20 minutes, it was maintained at $25^{\circ} \mathrm{C}$ 139and 100 rpm shaker platform (orbital shaker Kuhner, LS-X, Switzerland, r = 25 mm) . 140In the second case, broth produced by T. versicolor culture (sieved to remove the fungal 141pellets) containing $100 \mathrm{U} \mathrm{L}^{-1}$ of laccase enzyme was added to microalgal biomass 142following the same strategy as for commercial laccase.

144After the enzymatic pretreatment of microalgal biomass for 20 minutes, BMP tests were 145carried out in serum bottles of $160 \mathrm{~mL}$, with a working liquid volume of $100 \mathrm{~mL}$ and a 146headspace volume of $60 \mathrm{~mL}$. The inoculum was mesophilic digested sludge from an 147anaerobic digester of a municipal WWTP located in Gavà (Catalunya, Spain). Bottles 148contained a total organic matter concentration of $5 \mathrm{~g}$ COD/L and the substrate/inoculum 149(S/I) ratio was $0.5 \mathrm{~g}$ VS substrate/ g VS inoculum, based on previous studies, including 150one in which the S/I ratio was optimised for microalgal biomass grown in the same pilot 151HRAP [24,25]. Afterwards, bottles were filled with distilled water up to $100 \mathrm{~mL}$, 152flushed with helium gas, sealed with butyl rubber stoppers and incubated at $35^{\circ} \mathrm{C}$ until 153biogas production ceased. Biogas production was measured by the pressure increase in 154the headspace volume using an electronic manometer (Greisinger GMH 3151, error $155 \pm 0.1 \%)$. After each measurement, biogas was released from the reactor’s headspace 156until atmospheric pressure in the reactor was reached; afterwards reactors were 157manually shaken.

158The following trials were carried out: (1) microalgal biomass pretreated with 159commercial laccase, (2) microalgal biomass pretreated with fungal broth, (3) non160pretreated microalgal biomass control, (4) commercial laccase control, (5) fungal broth 161control, and (6) blank containing only inoculum, in order to quantify the methane 
162production by endogenous respiration. Blank results were subtracted from all trials to 163obtain the net biogas production. Furthermore, commercial laccase control results were 164subtracted from microalgal biomass pretreated with commercial laccase; whereas fungal 165broth control results were subtracted from microalgal biomass pretreated with fungal 166broth. All experimental trials, including pretreatments, controls and blank were 167performed in triplicate and expressed at standard temperature and pressure.

\subsection{Analytical methods}

169Glucose concentration was measured with an YSI 2000 enzymatic analyzer from Yellow 170Springs Instruments and Co.

171Laccase activity was measured using a modified version of the method for the 172determination of manganese peroxidase [26]: The reaction mixture used consisted of $173200 \mu \mathrm{L}$ of $250 \mathrm{mM}$ sodium malonate at $\mathrm{pH}$ 4.5, $50 \mu \mathrm{L}$ of $20 \mathrm{mM}$ 2,6-dimethoxyphenol 174(DMP) and $600 \mu \mathrm{L}$ of sample. DMP is oxidized by laccase even in the absence of 175cofactor. Changes in the absorbance at $468 \mathrm{~nm}$ were monitored for $2 \mathrm{~min}$ on a Varian 176Cary $3 \mathrm{UV}$-vis spectrophotometer at $30^{\circ} \mathrm{C}$. One activity unit (U) was defined as the 177number of micromoles of DMP oxidized per minute. The DMP extinction coefficient 178was $24.8 \mathrm{mM}^{-1} \mathrm{~cm}^{-1}[27]$.

179The inoculum and substrate were characterised (Table 1) by the concentration of total 180solids (TS), volatile solids (VS) and chemical oxygen demand (COD), following 181standard methods guidelines (APHA, 1999). $\mathrm{pH}$ was analysed with a Crison Portable $182506 \mathrm{pH}$-meter. The lipid content of biomass was determined by the Soxhlet extraction 183method [28, 29]. The total Kjeldahl nitrogen (TKN) to protein conversion factor was 1845.95, according to González López et al., [27]. Carbohydrates were determined by 185phenol-sulphuric acid method, after acid hydrolysis and measured by 186spectrophotometry (Spectronic Genesys 8) [30]. 
187The methane content in biogas was measured once a week with a gas chromatograph 188(GC) (Trace GC Thermo Finnigan) equipped with a Thermal Conductivity Detector, by 189injecting gas samples into a packed column (Hayesep 3m1/8 in. 100/120). The carrier 190gas was helium in splitless mode (column flow: $19 \mathrm{~mL} / \mathrm{min}$ ). The oven temperature was $19135{ }^{\circ} \mathrm{C}$ with a retention time of $1.5 \mathrm{~min}$. Injector and detector temperatures were 150 and $19225^{\circ} \mathrm{C}$, respectively. The system was calibrated with methane $\left(50 \% \mathrm{CH}_{4}\right)$ and carbon 193dioxide $\left(50 \% \mathrm{CO}_{2}\right)$.

194

\section{Results and discussion}

\section{$196 \quad 3.1 \quad$ Fungal broth production}

197Trametes versicolor cultured in Kirk's nutrient medium produces laccase enzyme and is 198appropriate for studying the ligninolytic activity of fungal cultures [31]. Laccase 199production and glucose consumption from Trametes versicolor culture are shown in 200Figure 1. Gradual glucose consumption along with laccase activity increase by the 201fungus T. versicolor can be observed. 


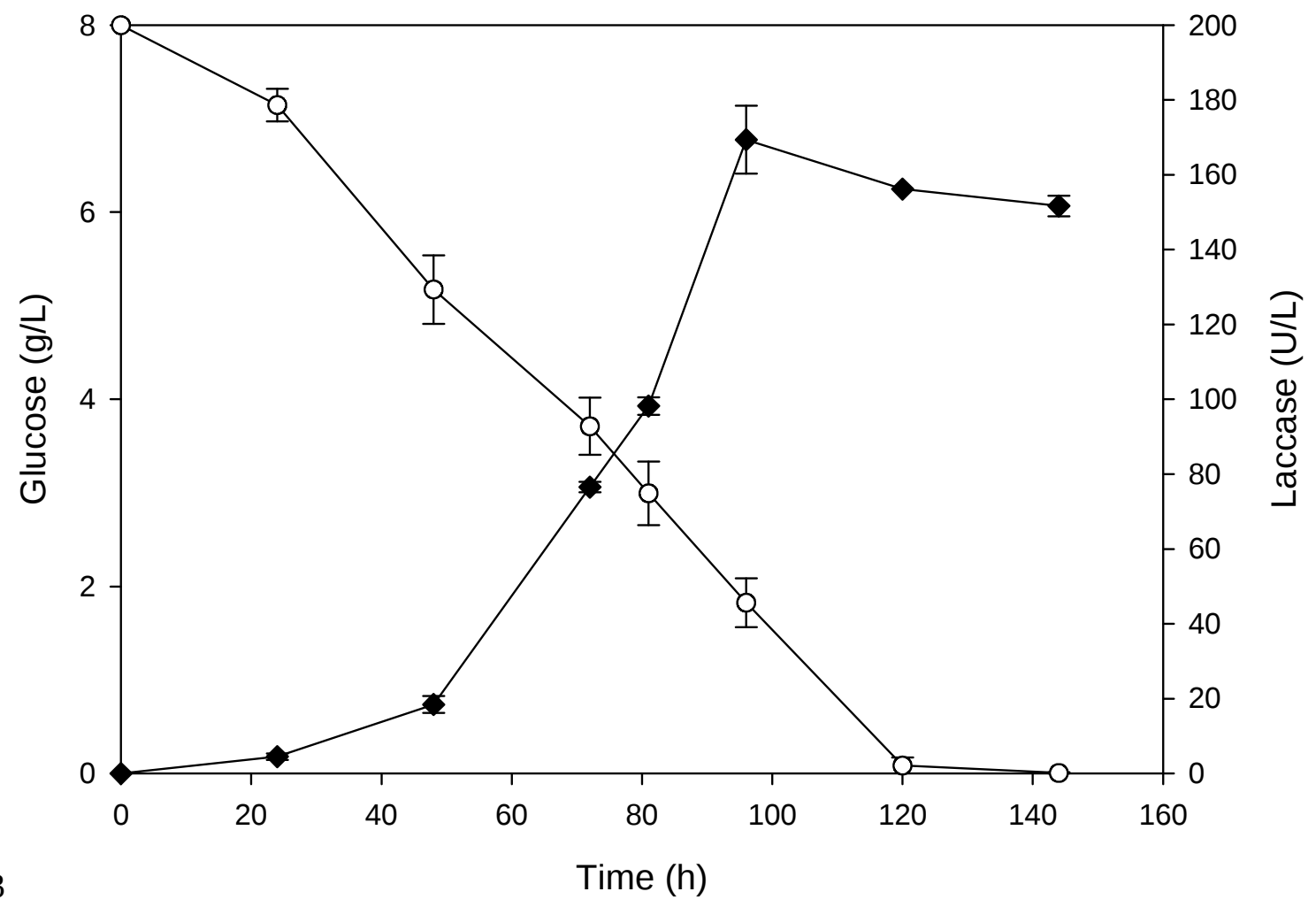

204Figure 1. Glucose consumption ( $($ ) and laccase production $(\diamond)$ by Trametes versicolor 205

206Laccase enzyme is excreted by T. versicolor to the broth and the excretion is associated 207to both growth and glucose consumption. Enzyme production increased over the first 4 208days and, after reaching a maximum activity level (170 $\mathrm{U} \mathrm{L}^{-1}, 4$ days), it dropped, since 209the carbon source (glucose) had been consumed. The same laccase activity behaviour 210was observed by other authors [15,32]. The fungal broth obtained from T. versicolor 211culture in Kirk's medium is mostly rich in laccase enzyme, among other enzymes or 212mediators, and unconsumed glucose. After 3 days of cultivation, other enzymes can be 213secreted by T. versicolor, such as cellulases and hemicellulases [33], possibly important 214for microalgae cell wall degradation.

\subsection{Biogas production in BMP test}

216The fungal broth and commercial laccase were applied at a dose of $100 \mathrm{U} \mathrm{L}^{-1}$ of laccase 217enzyme and were used as a pretreatment for microalgal biomass solubilisation in order 
218to evaluate the anaerobic biodegradability increase in BMP tests. The experiment lasted 21932 days, until accumulated biogas production reached an asymptote (Figure 2). As can 220be seen from the results, both pretreated trials increased the biogas production as 221compared to non-pretreated microalgae. Moreover, the fungal broth pretreatment 222attained the highest value. The methane content was measured along the experiment 223obtaining an average concentration of $68 \pm 4.5 \% \mathrm{CH}_{4}$. Control trials from both laccases 224(commercial and fungal broth) were subtracted from the corresponding pretreatment, 225along with the production of the inoculum, to obtain the net biogas and methane 226production along with the net methane yield (Table 2).

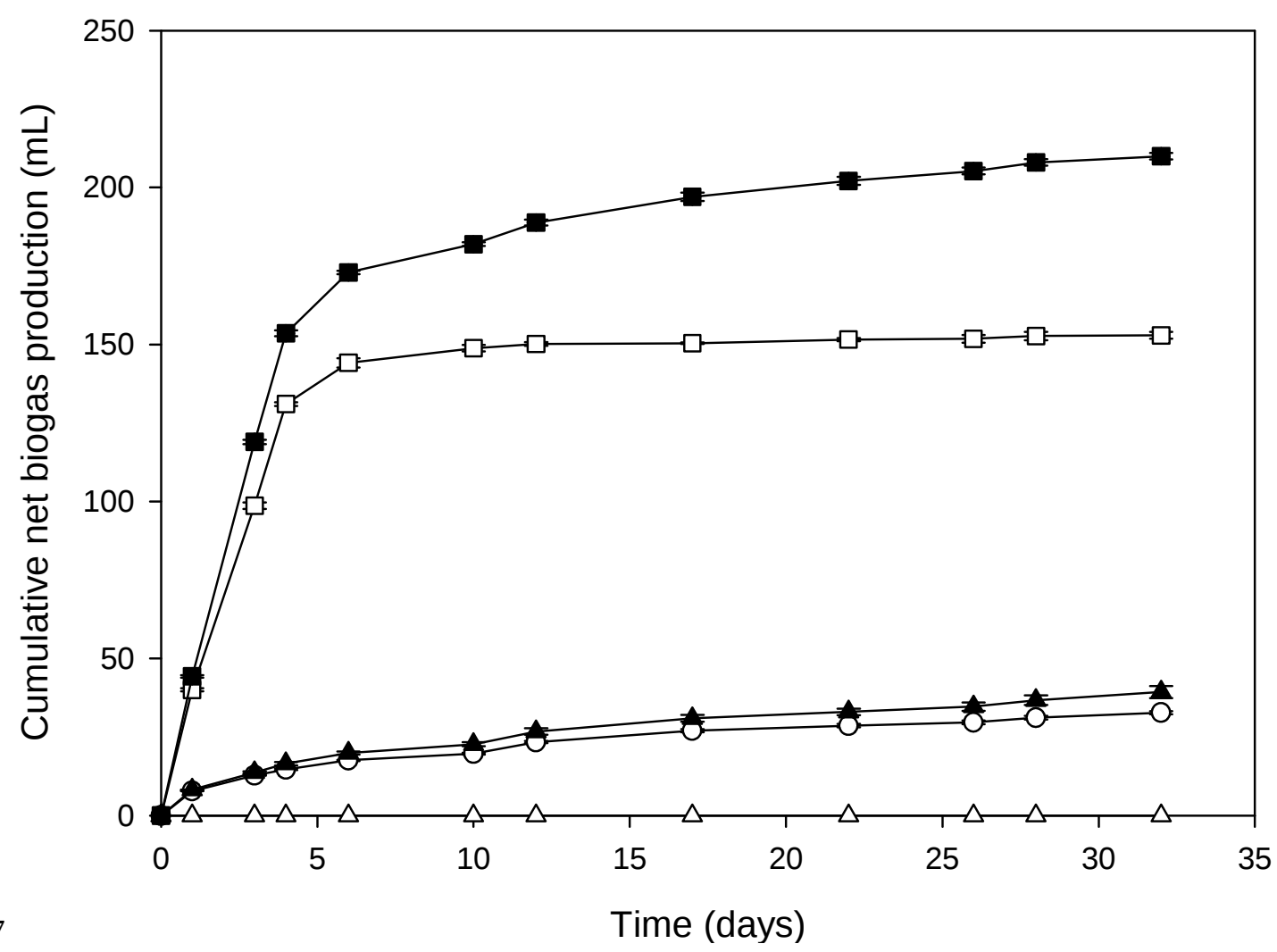

228Figure 2 Cumulative net biogas production for the anaerobic digestion of microalgal 229biomass using two enzymatic pretreatments and their respective controls. Commercial 230laccase control ( $\square$ ); Microalgal biomass control (O); Commercial laccase pretreatment

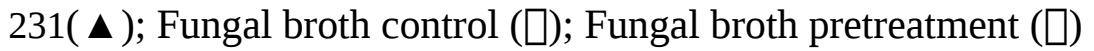


233Table 2 Net methane production and yield for the different trials of the BMP test

\begin{tabular}{lccc}
\hline Trial & $\begin{array}{c}\text { Biogas } \\
\text { productio } \\
\mathbf{n}\end{array}$ & $\begin{array}{c}\text { Methane } \\
\text { production } \\
\left(\mathbf{m L} \mathbf{C H}_{\mathbf{4}}\right)\end{array}$ & $\begin{array}{c}\text { Methane yield } \\
\left(\mathbf{m L} \mathbf{~ C H} \mathbf{~ g ~ V S ~}^{-\mathbf{1}}\right)\end{array}$ \\
\hline Microalgal biomass control & $33 \pm 0.5$ & $22 \pm 0.5$ & $83 \pm 1$ \\
Commercial laccase control & 0.0 & 0.0 & - \\
Fungal broth control & $153 \pm 1.1$ & $104 \pm 1.1$ & - \\
Commercial laccase & $40 \pm 1.3$ & $27 \pm 1.3$ & $100 \pm 7$ \\
pretreatment & $210 \pm 0.3$ & $143 \pm 0.3$ & $144 \pm 2$ \\
Fungal broth pretreatment & & &
\end{tabular}

235Regarding the control trials, commercial laccase control did not produce any biogas.

236Microalgal biomass control produced little methane (22 $\left.\mathrm{mL} \mathrm{CH}_{4}\right)$, whereas the fungal

237broth control produced $104 \mathrm{~mL} \mathrm{CH}_{4}$. Indeed, reactors containing fungal broth produced

238more biogas than the rest, since they contained part of the nutrients (mainly glucose)

239present in the media for laccase production, which were not completely consumed by $T$.

240versicolor. This can be seen from Fig. 1: when $100 \mathrm{U} \mathrm{L}^{-1}$ of laccase were obtained, the

241concentration of glucose was $3 \mathrm{~g} \mathrm{~L}^{-1}$. The amount of biogas produced from glucose

242remaining in the culture broth was theoretically calculated and compared with

243experimental results, using the Buswell equation [34] (equation 1 and 2). According to

244this, $112 \mathrm{~mL} \mathrm{CH}_{4}$ should have been theoretically produced, due to the remaining glucose

245of the medium, moreover this value does not exceed the mass-energy balance (374 mL

$246 \mathrm{CH}_{4} / \mathrm{g} \mathrm{C}_{6} \mathrm{H}_{12} \mathrm{O}_{6}$ ). This theoretical value is in accordance with the experimental one (104

$\left.247 \mathrm{~mL} \mathrm{CH}_{4}\right)$.

$248 C_{n} H_{a} O_{b}+\left(\frac{4 n-a-2 b}{4}\right) H_{2} O \rightarrow\left(\frac{4 n+a-2 b}{8}\right) C H_{4}+\left(\frac{4 n-a+2 b}{8}\right) C O_{2}(1)$

$249 B_{o, t h}\left[\frac{L C H_{4}}{g C_{n} H_{a} O_{b}}\right]=\frac{1}{8}\left(\frac{4 n+a-2 b}{12 n+a+16 b}\right) V_{m}(2)$

250where $\mathrm{V}_{\mathrm{m}}$ is the molar volume of methane at standard temperature and pressure. 
251The presence of glucose could also enhance the proliferation of anaerobic

252microorganisms, which may contribute to an increase of biogas production if it

253functions as a substrate to some microorganisms, which at the same time could produce 254some enzymes capable to further degrade the microalgal biomass, increasing the 255methane yield. However, since this effect cannot be measured, only the methane 256production due to glucose contribution was subtracted 257With regards to the pretreatment trials, commercial laccase pretreatment increased the 258methane yield by 20\%, whereas fungal broth pretreatment increased the methane yield 259by $74 \%$ relative to non-pretreated biomass. The results suggest that laccase may 260solubilise part of the microalgal biomass substrate, enhancing its bioavailability and/or 261biodegradability by anaerobic microorganisms. However, better results were achieved 262using the fungal broth. This is probably due to the presence of other enzymes, radicals 263and other mediators produced by T. versicolor during its culture, which may also 264contribute to microalgal biomass solubilisation [19]. It is worth pointing out that even 265though laccase is not specifically active on glycoproteins and polysaccharides (the main 266components of microalgal cell wall), the pretreatment was effective. Therefore, results 267confirm that laccase played a role on microalgae enzymatic pretreatment, although a 268mixture of different enzymes would be preferred. This is common for complex cultures, 269such as the one of the present study, composed by several microalgae species, bacteria 270and other microorganisms with different cell wall compositions. The results are in 271accordance with previous studies, where microalgae methane yield was increased when 272non-specific enzymes were added confirming the synergistic effect $[10,12,13]$. 273Nevertheless, a previous study using filamentous microalgae reported higher values 274than those obtained in our study. Ehimen et al. [10] obtained 115-145 mL CH $4 / \mathrm{g}$ TS 275after an enzymatic pretreatment over 2 days, whereas the values obtained in the present 
276study were 63 and $91 \mathrm{~mL} \mathrm{CH} / \mathrm{g}$ TS for commercial laccase and fungal broth 277pretreatment, respectively, after 20 minutes of enzymatic pretreatment. From these 278results, contact time seems to be an important parameter that should be further 279investigated. The methane yield of Chlorella vulgaris was increased by $14 \%$ after 280pretreatment with the hydrolytic enzyme carbohydrolase and by $51 \%$ after pretreatment 281with protease after an exposure time of $5 \mathrm{~h}$. Moreover, the same study with 282Chlamydomonas reinhardtii showed no increase after pretreatment with carbohydrolase 283and only 8\% increase after pretreatment with protease [35]. This increase was lower 284than the ones obtained in our study (20 and 74\% increase) and highlights that 285pretreatment effectiveness is species-specific and depends on the biomass complexity 286and composition.

287Finally, the results obtained in this study demonstrates that enzymatic pretreatment may 288be applied to microalgae anaerobic digestion, with better results for crude fungal 289enzymes probably due to the presence of other enzymes and other molecules produced 290by the fungus. This may be more cost-effective compared to commercial enzymes. 291Nevertheless, these results should be evaluated in continuous reactors for energy and 292economic aspects.

\section{Conclusions}

295This study aimed at investigating the effect of laccase, a non-specific enzyme, on 296microalgal biomass from a pilot-scale urban wastewater treatment system as a 297pretreatment step prior to its anaerobic digestion. Comparing the effect of commercial 298laccase and the fungal broth from Trametes versicolor, better results were observed for 299the fungal broth, which may be due to the synergistic effect of laccase and other radicals 300or molecules produced by T. versicolor. The methane yield was increased by $20 \%$ for 
301commercial laccase and 74\% for fungal broth, as compared to non-pretreated biomass. 302Thus, these findings should be investigated in continuous anaerobic reactors for 303evaluating full-scale viability.

304

\section{Acknowledgements}

306This work was funded by the Spanish Ministry of Economy and Competitiveness and 307FEDER (CTM2013-48545-C2-1-R and CTQ2014-57293-C3-3-R) and supported by the 308Generalitat de Catalunya (Consolidated Research Groups 2014SGR476 and 3092014SGR116). The Department of Chemical Engineering of the Universitat Autònoma 310de Barcelona is member of the Xarxa de Referència en Biotecnologia de la Generalitat 311de Catalunya. Andrea Hom-Diaz acknowledges her PhD scholarship from AGAUR 312(2013FI_B 00302). Fabiana Passos appreciates her Post-Doctorate scholarship funded 313by the National Council for Scientific and Technological Development (CNPq) from the 314Brazilian Ministry of Science, Technology and Innovation.

\section{References}

317[1] J.B.K. Park, R.J. Craggs, A.N. Shilton, Wastewater treatment high rate algal 318 ponds for biofuel production, Bioresour. Technol. 102 (2011) 35-42.

319 doi:10.1016/j.biortech.2010.06.158.

320[2] C. Zamalloa, E. Vulsteke, J. Albrecht, W. Verstraete, The techno-economic 321 potential of renewable energy through the anaerobic digestion of microalgae, 322 Bioresour. Technol. 102 (2011) 1149-58. doi:10.1016/j.biortech.2010.09.017.

323[3] A.J. Ward, D.M. Lewis, F.B. Green, Anaerobic digestion of algae biomass: A 324 review, Algal Res. 5 (2014) 204-214. doi:10.1016/j.algal.2014.02.001.

325[4] F. Passos, E. Uggetti, H. Carrère, I. Ferrer, Pretreatment of microalgae to improve biogas production: A review, Bioresour. Technol. 172 (2014) 403-412.

328[5] F. Passos, J. Carretero, I. Ferrer, Comparing pretreatment methods for improving 329 microalgae anaerobic digestion: Thermal, hydrothermal, microwave and 330 ultrasound, Chem. Eng. J. 279 (2015) 667-672. doi:10.1016/j.cej.2015.05.065.

331[6] H.G. Gerken, B. Donohoe, E.P. Knoshaug, Enzymatic cell wall degradation of 
$332 \quad$ Chlorella vulgaris and other microalgae for biofuels production, Planta. 237

333 (2013) 239-253. doi:10.1007/s00425-012-1765-0.

334[7] J.H. Mussgnug, V. Klassen, A. Schlüter, O. Kruse, Microalgae as substrates for 335 fermentative biogas production in a combined biorefinery concept, J. Biotechnol.

336150 (2010) 51-56. doi:10.1016/j.jbiotec.2010.07.030.

337[8] A. Mahdy, L. Mendez, M. Ballesteros, C. González-Fernández, Autohydrolysis and alkaline pretreatment effect on Chlorella vulgaris and Scenedesmus sp.

339 methane production, Energy. 78 (2014) 48-52. doi:10.1016/j.energy.2014.05.052.

340[9] C.-Y. Chen, X.-Q. Zhao, H.-W. Yen, S.-H. Ho, C.-L. Cheng, D.-J. Lee, et al., $341 \quad$ Microalgae-based carbohydrates for biofuel production, Biochem. Eng. J. 78 342 (2013) 1-10. doi:10.1016/j.bej.2013.03.006.

343[10] E.A. Ehimen, J.B. Holm-Nielsen, M. Poulsen, J.E. Boelsmand, Influence of 344 different pre-treatment routes on the anaerobic digestion of a filamentous algae, 345 Renew. Energy. 50 (2013) 476-480. doi:10.1016/j.renene.2012.06.064.

346[11] S.P. Choi, M.T. Nguyen, S.J. Sim, Enzymatic pretreatment of Chlamydomonas 347 reinhardtii biomass for ethanol production, Bioresour. Technol. 101 (2010) 5330$348 \quad$ 5336. doi:10.1016/j.biortech.2010.02.026.

349[12] F. Passos, A. Hom-Diaz, P. Blanquez, T. Vicent, I. Ferrer, Improving biogas $350 \quad$ production from microalgae by enzymatic pretreatment, Bioresour. Technol. 199 351 (2015) 347-351. doi:10.1016/j.biortech.2015.08.084.

352[13] S.K. Prajapati, A. Bhattacharya, A. Malik, V.K. Vijay, Pretreatment of algal 353 biomass using fungal crude enzymes, Algal Res. 8 (2015) 8-14.

354 doi:10.1016/j.algal.2014.12.011.

355[14] S.B. Pointing, Feasibility of bioremediation by white-rot fungi, Appl. Microbiol. $356 \quad$ Biotechnol. 57 (2001) 20-33. doi:10.1007/s002530100745.

357[15] P. Blánquez, N. Casas, X. Font, X. Gabarrell, M. Sarrà, G. Caminal, et al., 358 Mechanism of textile metal dye biotransformation by Trametes versicolor , Water 359 Res. 38 (2004) 2166-72. doi:10.1016/j.watres.2004.01.019.

360[16] Č. Novotný, K. Svobodová, P. Erbanová, T. Cajthaml, A. Kasinath, E. Lang, et 361 al., Ligninolytic fungi in bioremediation: Extracellular enzyme production and 362 degradation rate, Soil Biol. Biochem. 36 (2004) 1545-1551.

363 doi:10.1016/j.soilbio.2004.07.019.

364[17] E. Marco-Urrea, M. Pérez-Trujillo, T. Vicent, G. Caminal, Ability of white-rot 365 fungi to remove selected pharmaceuticals and identification of degradation 366 products of ibuprofen by Trametes versicolor, Chemosphere. 74 (2009) 765-772. 367 doi:10.1016/j.chemosphere.2008.10.040.

368[18] M. Asgher, H.N. Bhatti, M. Ashraf, R.L. Legge, Recent developments in 369 biodegradation of industrial pollutants by white-rot fungi and their enzyme 370 system., Biodegradation. 19 (2008) 771-83. doi:10.1007/s10532-008-9185-3.

371[19] S. Riva, Laccases: blue enzymes for green chemistry, Trends Biotechnol. 24 372 (2006) 219-226. doi:10.1016/j.tibtech.2006.03.006.

373[20] W. Qiu, H. Chen, Enhanced the enzymatic hydrolysis efficiency of wheat straw 374 after combined steam explosion and laccase pretreatment., Bioresour. Technol. 
376[21] J. García, B.F. Green, T. Lundquist, R. Mujeriego, M. Hernández-Mariné, W.J.

377 Oswald, Long term diurnal variations in contaminant removal in high rate ponds

378 treating urban wastewater, Bioresour. Technol. 97 (2006) 1709-1715.

379 doi:10.1016/j.biortech.2005.07.019.

380[22] F. Passos, R. Gutiérrez, D. Brockmann, J.-P. Steyer, J. García, I. Ferrer,

381 Microalgae production in wastewater treatment systems, anaerobic digestion and modelling using ADM1, Algal Res. 10 (2015) 55-63.

383 doi:10.1016/j.algal.2015.04.008.

384[23] T.K. Kirk, L. Schultz, W.J. Connors, L.F. Lorenz, J.G. Zeikus, Influence of 385 culture parameters on lignin degradation by Phanerochaete chrysosporium, Arch. $386 \quad$ Microbiol. 117 (1978) 227-285.

387[24] M.E. Alzate, R. Muñoz, F. Rogalla, F. Fdz-Polanco, S.I. Pérez-Elvira, 388 Biochemical methane potential of microalgae: Influence of substrate to inoculum 389 ratio, biomass concentration and pretreatment, Bioresour. Technol. 123 (2012) 390 488-494. doi:10.1016/j.biortech.2012.06.113.

391[25] F. Passos, J. García, I. Ferrer, Impact of low temperature pretreatment on the anaerobic digestion of microalgal biomass., Bioresour. Technol. 138 (2013) 79393 86. doi:10.1016/j.biortech.2013.03.114.

394[26] E. Kaal, E. de Jong, J. Field, Stimulation of ligninolytic peroxidase activity by 395 nitrogen nutrients in the white rot fungus Bjerkandera sp. strain BOS55, Appl. 396 Environ. Microbiol. 59 (1993) 4031-6.

397[27] H. Wariishi, K. Valli, M.H. Gold, Manganese (II) oxidation by manganese 398 peroxidase from the basidiomycete Phanerochaete chrysosporium - Kinetic 399 mechanism and role of chelators, J. Biol. Chem. 267 (1992) 23688-23695.

400[28] APHA, AWWA, WPCF, Standard methods for the examination of water and 401 wastewater, 20th ed., American Public Health Association, American Water 402 Works Association, Water Environment Federation, Washington, DC, 1999.

403[29] C.V. González López, M. del C. Cerón García, F.G. Acién Fernández, C. Segovia 404

405

406

407[30] M. Dubois, K.A. Gilles, J.K. Hamilton, P.A. Rebers, F. Smith, Colorimetric 408 Method for Determination of Sugars and Related Substances, Anal. Chem. 28 409 (1956) 350-356.

410[31] N. Casas, P. Blánquez, T. Vicent, M. Sarrà, Laccase production by Trametes 411 versicolor under limited-growth conditions using dyes as inducers, Environ. 412 Technol. 34 (2013) 113-119. doi:10.1080/09593330.2012.683820.

413[32] M. Borchert, J.A. Libra, Decolorization of reactive dyes by the white rot fungus 414 Trametes versicolor in sequencing batch reactors, Biotechnol. Bioeng. 75 (2001) 415 313-21. doi:10.1002/bit.10026.

416[33] P. Singh, O. Sulaiman, R. Hashim, L.C. Peng, R.P. Singh, Evaluating biopulping as an alternative application on oil palm trunk using the white-rot fungus

418 Trametes versicolor, Int. Biodeterior. Biodegrad. 82 (2013) 96-103. 
419 doi:10.1016/j.ibiod.2012.12.016.

420[34] G.E. Symons, A.M. Buswell, The methane fermentation of carbohydrates, J. Am. 421 Chem. Soc. 55 (1933) 2028-2036. doi:10.1021/ja01332a039.

422[35] A. Mahdy, L. Mendez, M. Ballesteros, C. González-Fernández, Enhanced 423 methane production of Chlorella vulgaris and Chlamydomonas reinhardtii by 424 hydrolytic enzymes addition, Energy Convers. Manag. 85 (2014) 551-557. 425 doi:10.1016/j.enconman.2014.04.097.

426 